\title{
Effects of temperature and food concentration on the survival, development and growth rates of naupliar stages of Oithona davisae (Copepoda, Cyclopoida)
}

\author{
Rodrigo Almeda*, Albert Calbet, Miquel Alcaraz, Lidia Yebra, Enric Saiz
}

Institut de Ciències del Mar (CSIC), P. Marítim de la Barceloneta 37-49, 08003 Barcelona, Spain

\begin{abstract}
Oithona spp. are probably the most abundant and ubiquitous copepods in the world's oceans. However, knowledge of their development and growth rates is scarce compared to that of calanoid copepods. In the present laboratory study, we determined the survival, development and growth rates of the naupliar stages of Oithona davisae under different temperature regimes and food concentrations. Naupliar survival was reduced to approximately $60 \%$ at the lowest food concentration tested $\left(11 \mu \mathrm{g} \mathrm{Cl}^{-1}\right.$ after $7 \mathrm{~d}$ at $\left.20^{\circ} \mathrm{C}\right)$. The development of $O$. davisae nauplii was equiproportional, but not isochronal. Food concentrations required for maximum development and growth rates were 56 and $87 \mu \mathrm{g} \mathrm{Cl}^{-1}$, respectively. The $Q_{10}$ values for development and growth depended on the temperature range. $O$. davisae nauplii showed similar developmental times, but lower growth rates and food requirements than values reported in the literature for calanoid copepods. We suggest that these differences may help to explain the ubiquity of Oithona spp. in oceanic environments.
\end{abstract}

KEY WORDS: Nauplii · Oithona davisae · Growth · Development · Survival · Food · Temperature

\section{INTRODUCTION}

Copepod nauplii are under-studied components of plankton communities, even though they are the most abundant metazoans on the planet (Björnberg 1986, Fryer 1986) and the main prey for many fish larvae of commercially important species (Last 1980). The lack of information about naupliar ecology is partially because they have been under-sampled by conventional methods, such as plankton nets of $200 \mu \mathrm{m}$ mesh (Alcaraz 1977, Calbet et al. 2001, Gallienne \& Robins 2001). With the use of appropriately sized plankton nets, nauplii have frequently been found to outnumber late copepodites and adults by several orders of magnitude (Calbet et al. 2001, Turner 2004). They can also sometimes represent a comparable or higher fraction of copepod biomass than older life stages (Castellani et al. 2007).

Knowledge of copepod life history, such as larval survival, development and growth rates, under different environmental conditions is essential to comprehending their population dynamics. Many field and laboratory studies have shown that water temperature and food concentration are the most important environmental factors influencing development, growth and survival of copepods (see reviews by Huntley \& Boyd 1984, Huntley \& Lopez 1992, Hirst \& Lampitt 1998, Hirst \& Kiørboe 2002). However, most studies have focused on adults or late copepodites (Hart 1990, Hirst \& Bunker 2003), while naupliar life stages have received less attention. Therefore, information about copepod naupliar ecophysiology is crucial in order to gain a better understanding of the role of zooplankton in marine biogenic fluxes. From an economic perspective, copepod nauplii are preferred and nutritious food sources for many farm-raised marine fish and shrimp larvae (Hernández-Molejón \& Álvarez-Lajonchère 2003 and references therein). Therefore, knowledge about the food requirements and experimental conditions for optimal growth and production of nauplii in the laboratory may be useful for aquaculture operations.

Among marine planktonic copepods, the genus Oithona (Cyclopoida) is probably the most abundant 
and ubiquitous copepod in the world's oceans (Gallienne \& Robins 2001). Nevertheless, knowledge about the biology and ecology of these small copepods is limited compared to the vast body of research devoted to larger calanoid copepods (Paffenhöfer 1993, Turner 2004). Information is available on Oithona spp. development and fecundity (Sabatini \& Kiørboe 1994, Uye \& Sano 1995, Peterson 2001, Castellani et al. 2005a). However, studies are scarce on growth rates of Oithona spp. nauplii as a function of environmental variables, such as food concentration and temperature (Sabatini \& Kiørboe 1994, Hopcroft \& Roff 1998). To partially fill this knowledge gap, we have examined the effects of temperature and food concentration on survival, development and growth rates of Oithona davisae nauplii in the laboratory. This species inhabits eutrophic embayments and may occasionally dominate the copepod community (Uye \& Sano 1995). It is indigenous to western Pacific, coastal areas, but is also an invasive species along the United States west coast (Ferrari \& Orsi 1984), southern Chilean coast (Hirakawa 1988) and the Spanish Mediterranean (Saiz et al. 2003).

\section{MATERIALS AND METHODS}

Experimental organisms. Oithona davisae specimens came from a continuous culture maintained in our laboratory since October 2000 (Saiz et al. 2003). Specifically, specimens were grown in 201 methacrylate tanks at $20 \pm 1^{\circ} \mathrm{C}$ in a room maintained at constant temperature and under a $12 \mathrm{~h}$ light:12 h dark cycle. Copepod cultures were fed ad libitum a suspension of the heterotrophic dinoflagellate Oxyrrhis marina (equivalent spherical diameter $[\mathrm{ESD}]=15 \mu \mathrm{m}$ ). $O$. marina were fed the cryptophyte Rhodomonas salina $(\mathrm{ESD}=8 \mu \mathrm{m})$. Prey sizes were measured by a Coulter Multisizer III particle counter (Beckman Coulter).

To obtain cohorts of nauplii, we removed adults (including egg-bearing females) from the stock culture with a $132 \mu \mathrm{m}$ sieve and placed them in a new tank where they were fed Oxyrrhis marina ad libitum (i.e. $>3000$ cells ml ${ }^{-1}$, equivalent to $>660 \mu \mathrm{g} \mathrm{Cl}^{-1}$ ). Adults were removed with a $100 \mu \mathrm{m}$ sieve after $20 \mathrm{~h}$, and the hatched nauplii were transferred to a new tank. To isolate the dislodged egg sacs, we allowed them to settle for $2 \mathrm{~h}$ before siphoning the nauplii into new tanks.

Experimental design and general procedures. We examined the survival, development and growth of Oithona davisae naupliar life stages as they relate to food concentrations (i.e. food-effects experiment). A cohort of nauplii was split into aliquots of about 4000 nauplii each that were placed into 101 methacrylate tanks containing Oxyrrhis marina suspensions at different concentrations $(50,200,400,600$ and 1200 cells $\mathrm{ml}^{-1}$, equivalent to $11,44,88,132$ and $265 \mu \mathrm{g} \mathrm{Cl}^{-1}$, respectively). The $O$. marina volume was converted to $\mathrm{C}$

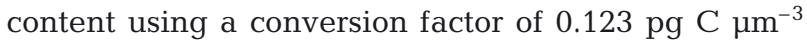
provided by Pelegri et al. (1999). The $O$. marina cultures used in our experiments were not fed the day before use, to ensure that the dinoflagellate depleted all the Rhodomonas salina and that only $O$. marina was offered as prey. The absence of $R$. salina in stock bottles was verified with a Coulter Multisizer particle counter. Nauplii were incubated for $7 \mathrm{~d}$ at $20 \pm 1^{\circ} \mathrm{C}$ in a temperature-controlled room under a $12 \mathrm{~h}$ light:12 h dark cycle. Time was measured relative to the starting time of incubations of egg-bearing females.

Food concentrations were checked daily using a Coulter Multisizer III particle counter. Variations in food concentrations between daily adjustments were frequently $<20 \%$ and never exceeded $40 \%$ of the corresponding food level. Each experimental container was sampled every $24 \mathrm{~h}$ by filtering an aliquot of water through a $32 \mu \mathrm{m}$ sieve. This isolated at least 200 individuals for subsequent counting, measuring and staging. Naupliar samples were preserved with Lugol's solution. The original water volume in the experimental containers was kept constant by daily adjustments with either fresh Oxyrrhis marina from stock cultures or alternatively by adding filtered $(0.2 \mu \mathrm{m})$ seawater.

A second experiment was conducted to examine the influence of temperature on survival, development and growth of Oithona davisae naupliar stages (i.e. temperature-effects experiment). Five temperatures were tested $\left(12,16,20,24\right.$ and $\left.28^{\circ} \mathrm{C}\right)$ under satiating food concentrations $\left(>2000\right.$ cells ml $^{-1}$ ). Approximately 8000 nauplii from each temperature tested were placed in 21 Pyrex glass bottles. These individuals were fed Oxyrrhis marina for $7 \mathrm{~d}$ under a $12 \mathrm{~h}$ light: $12 \mathrm{~h}$ dark cycle. Temperatures were maintained at $\pm 0.2^{\circ} \mathrm{C}$ of the desired temperature using water-baths controlled by thermoregulators. Daily food adjustments were made to maintain food satiation during the experiment. All other procedures were the same as those described for the food-effects experiment.

Body length-weight relationships. To estimate weight-specific growth rates (see below), we determined the body length-weight relationships of Oithona davisae nauplii and copepodites. Samples from naupliar cohorts were taken over the course of their development. These samples were concentrated using 37 and $60 \mu \mathrm{m}$ sieves for nauplii and copepodites, respectively, and rinsed thoroughly in autoclaved and filtered $(0.2 \mu \mathrm{m})$ seawater. Three aliquots containing 1000 individuals each were filtered onto pre-incinerated $\left(450^{\circ} \mathrm{C}, 6 \mathrm{~h}\right)$ glass-fibre filters (GF/A grade), after which the filters were dried $\left(60^{\circ} \mathrm{C}, 24 \mathrm{~h}\right)$ and stored in a vacuum desiccator (with silica gel) for further analysis of organic $\mathrm{C}$ and $\mathrm{N}$ content. Three additional ali- 
quots of $\sim 100$ individuals per replicate) were fixed in a $4 \%$ borax-buffered formaldehyde solution for the counting of larvae and length determinations. The $\mathrm{C}$ and $\mathrm{N}$ content of the larvae were determined by a Perkin-Elmer 2400 CHN Elemental Analyzer. Total larvae per aliquot were counted with an inverted microscope (40× magnification). Body sizes $(L, \mu \mathrm{m})$ of $O$. davisae larvae (copepodites: prosome length; nauplii: total length) were measured by capturing digital pictures of at least 50 individuals under a microscope (100× magnification) and using ImageJ software for quantitative analysis. Relationships between body weight (measured as $\mathrm{C}$ and $\mathrm{N}$ mass) and body size for both nauplii and copepodites were calculated by regression analysis.

Estimates of survival, development and growth rates. Larval survival $(S)$ in each incubation container was estimated daily by subsampling as described above and applying the following calculation:

$$
S_{X}(\%)=\left[\left(N_{X} \times V_{\text {tank }} / V_{\text {aliqout }}+N_{\mathrm{R}}\right) / N_{\mathrm{i}}\right] \times 100
$$

where $N_{x}$ is the current number of live larvae estimated from the aliquot at Day $x, N_{\mathrm{R}}$ is the number of larvae removed on previous days, $N_{\mathrm{i}}$ is the number of initial larvae and $V_{\text {tank }}$ and $V_{\text {aliqout }}$ are the tank and aliquot volume, respectively.

Samples were counted using an inverted microscope at $40 \times$ magnification, and the developmental stages of at least 40 individuals per incubation container were determined with microscopy at $100 \times$ magnification according to Uchima (1979). Stage-specific median development time (MDT) and stage duration (SD) were calculated from observed changes in stage frequency over time (see Table 1 for terminology and definitions). The stage-specific MDT was calculated as the time required for $50 \%$ of the individual organisms in culture to moult to the following stage (Landry 1983). The MDT for a given developmental stage was estimated by fitting a sigmoidal Hill function to the cumulative proportion of that stage over time:

$$
y=a \times t^{b} /\left(\mathrm{MDT}^{b}+t^{b}\right)
$$

where $y$ is the cumulative percentage of each stage, $t$ is the time (d) since females were separated, $a$ is the highest $y$-axis value (i.e. $100 \%$ when the entire cohort is in early developmental stages), MDT is the $t$ value that produces $50 \%$ of the $y$-axis value and $b$ is the shape coefficient.

Stage-specific development rates $\left(D, \mathrm{~d}^{-1}\right)$ were calculated as the inverse of the MDT. The stage duration was estimated as the difference in MDT of 2 consecutive developmental stages. The equiproportional rule of copepods (i.e. the duration of a given life-history stage occupies a constant proportion of the total or egg developmental time regardless of temperature; Corkett 1984) was tested considering the proportion of time that each stage occupied with respect to the total naupliar development time (time between egg hatching and moult into the first copepodite stage [CI]).

For specific growth rate determinations, the body lengths of 50 random individuals from each cohort were measured daily, and their $\mathrm{C}$ weights were calculated by applying body size to $\mathrm{C}$ content relationships. Additionally, we measured 30 individuals per treatment at each developmental stage (from Nauplus Stage I to VI, NI to NVI) to estimate the effects of temperature and food concentration on naupliar body length. In all cases, body length was determined using ImageJ software, as mentioned previously. Weightspecific growth rates $\left(G, \mathrm{~d}^{-1}\right)$ were calculated as the slope of regression lines relating the natural logarithm of $\mathrm{C}$ biomass to incubation time.

\begin{tabular}{|c|c|c|c|}
\hline Symbol & Term & Unit & Explanation \\
\hline MDT & Median developmental time & $\mathrm{d}$ & $\begin{array}{l}\text { Time at which } 50 \% \text { of the larvae in the culture has } \\
\text { moulted to the following stage }\end{array}$ \\
\hline $\mathrm{SD}$ & Stage duration & $\mathrm{d}$ & Difference in MDT of 2 consecutives stages \\
\hline$D$ & Developmental rates & $\mathrm{d}^{-1}$ & Inverse of MDT \\
\hline$D_{\max }$ & Maximum development rate & $\mathrm{d}^{-1}$ & From Ivlev's equation \\
\hline$W$ & Weight & $\mathrm{ng}$ & \\
\hline$L$ & Length & $\mu \mathrm{m}$ & \\
\hline$G$ & Specific growth rates & $d^{-1}$ & \\
\hline$G_{\max }$ & Maximum specific growth rates & $\mathrm{d}^{-1}$ & From Ivlev's equation \\
\hline C & Food concentration & $\mu g \mathrm{Cl}^{-1}$ & \\
\hline$C_{\mathrm{D}}$ & Satiating food concentration for development & $\mu \mathrm{g} \mathrm{C} 1^{-1}$ & Food concentration required to achieve $95 \%$ of $D_{\max }$ \\
\hline$C_{\mathrm{G}}$ & Satiating food concentration for growth & $\mu g \mathrm{Cl}^{-1}$ & Food concentration required to achieve $95 \%$ of $G_{\max }$ \\
\hline
\end{tabular}

Table 1. Terminology and units 
Temperature coefficient $\left(Q_{10}\right)$ values for the temperature-effects experiment were calculated as:

$$
Q_{10}=\left(M_{2} / M_{1}\right)^{10 /(T 2-T 1)}
$$

where $M_{2}$ and $M_{1}$ are the rates of the studied process at temperatures $T_{2}$ and $T_{1}\left({ }^{\circ} \mathrm{C}\right)$, respectively.

All statistical analyses and regressions were conducted with SPSS 17.0 software. All curves were fitted by standard least-squares procedures using Sigma plot 9.0 software.

\section{RESULTS}

\section{Elemental composition $(\mathrm{C}, \mathrm{N})$ of Oithona davisae nauplii and copepodites}

The relationships between body weight ( $W$, organic $\mathrm{C}$ and $\mathrm{N})$ and body length $(L, \mu \mathrm{m})$ of nauplii and copepodites are shown in Fig. 1A, B. The fitted equations were:

$$
\begin{aligned}
& W(\text { ng } \mathrm{C})=0.0021 \times L^{2.14}, \mathrm{r}^{2}=0.96 \text { for nauplii } \\
& W(\text { ng } \mathrm{N})=7.47 \times 10^{-6} \times L^{2.92}, \mathrm{r}^{2}=0.98 \text { for nauplii } \\
& W(\text { ng } \mathrm{C})=0.0318 \times L^{1.61}, \mathrm{r}^{2}=0.94 \text { for copepodites } \\
& W(\text { ng } \mathrm{N})=0.0091 \times L^{1.58}, \mathrm{r}^{2}=0.99 \text { for copepodites }
\end{aligned}
$$

The C:N ratio decreased during larval development of Oithona davisae (Fig. 1C). Nauplii showed gradual decreases from 8.4 (NI to NII) to 5.4 (NV to NVI) in their $\mathrm{C}: \mathrm{N}$ ratios with increasing age/size. In contrast, $\mathrm{C}: \mathrm{N}$ ratios in copepodites varied only slightly between developmental stages, with an average value of 4.12. The relationship between the $\mathrm{C}: \mathrm{N}$ ratio and body length $(L, \mu \mathrm{m})$ of nauplii $O$. davisae is described by the equation (Fig. 1C):

$$
\mathrm{C}: \mathrm{N}=239 \times(1+L)^{-0.74}, \mathrm{r}^{2}=0.96
$$

\section{Survival}

Naupliar survival was high (>91\%) at all food levels, except at the lowest food concentration (11 $\left.\mathrm{\mu g} \mathrm{l}^{-1}\right)$, where survivorship declined to $58 \%$ by the end of the incubation (Fig. 2A). Regarding the temperatureeffects experiment, naupliar survival was also high (85 to $93 \%$ ) at all temperatures and decreased only slightly with rising temperature (Fig. 2B). In both experiments, differences between treatments started to be evident after the fifth incubation day (Fig. 2). We observed a slight increase in mortality in treatments where nauplii underwent metamorphosis to the CI developmental stage (Fig. 2).

\section{Development rates}

The cumulative abundance percentage of each naupliar stage over time at the different temperatures and food conditions is presented in Fig. 3. In all cases, these data fitted the Hill functions well $(\mathrm{p}<0.05)$.

Effects of food concentration. The cumulative percentage fits among the low-food treatments covered a wider range than the higher food concentrations (Fig. 3 , right panels) because of the slower development at these food levels. Cohorts reached CI within the $7 \mathrm{~d}$ incubation time at all food concentrations except the lowest. MDT for each naupliar stage decreased with increasing food concentrations, leading to a decrease in the developmental stage duration (Table 2). Naupliar development was not isochronal, because the duration of the late naupliar stage, particularly NVI, was longer than other developmental stages. Naupliar development was nearly equiproportional at high food levels $\left(\geq 88 \mu \mathrm{g} \mathrm{C}^{-1}\right)$. Development rates $\left(D, \mathrm{~d}^{-1}\right)$ related to food concentration $\left(C, \mu \mathrm{g} \mathrm{C}^{-1}\right)$ were fitted to the
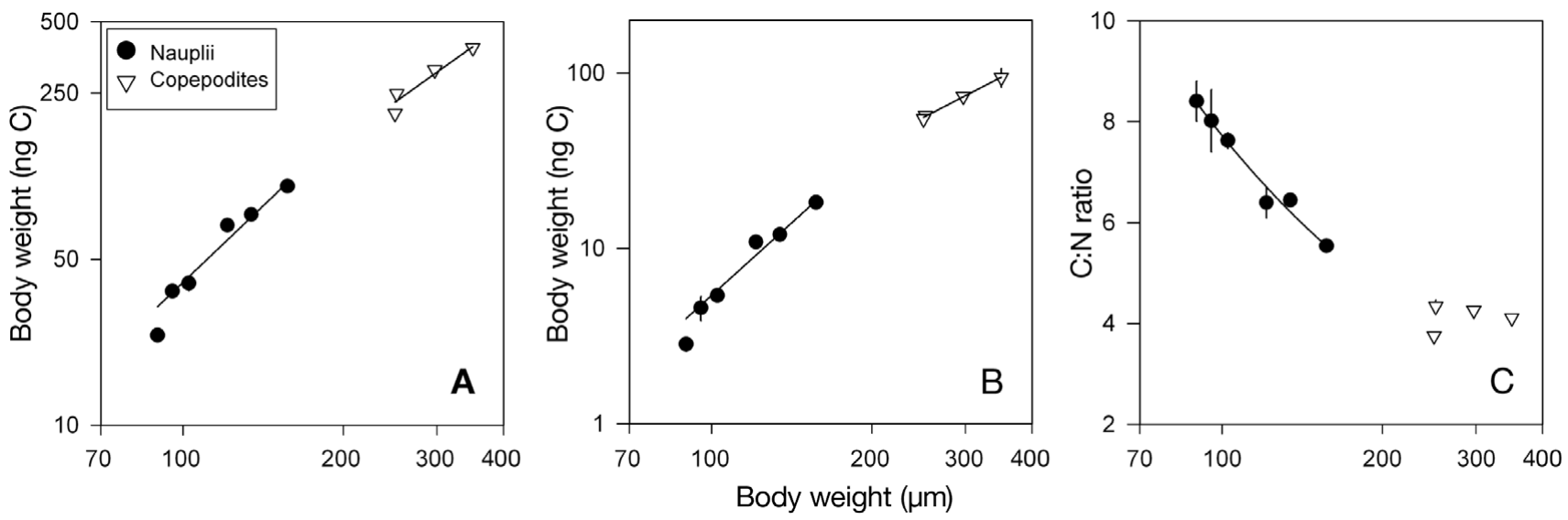

Fig. 1. Oithona davisae. Relationships between body length (total length for nauplii and prosome for copepodites) and (A) body carbon weight, (B) nitrogen weight and $(\mathrm{C})$ the ratio of carbon to nitrogen $(\mathrm{C}: \mathrm{N})$ of the developmental stages. Error bars represent $\pm \mathrm{SE}$ 


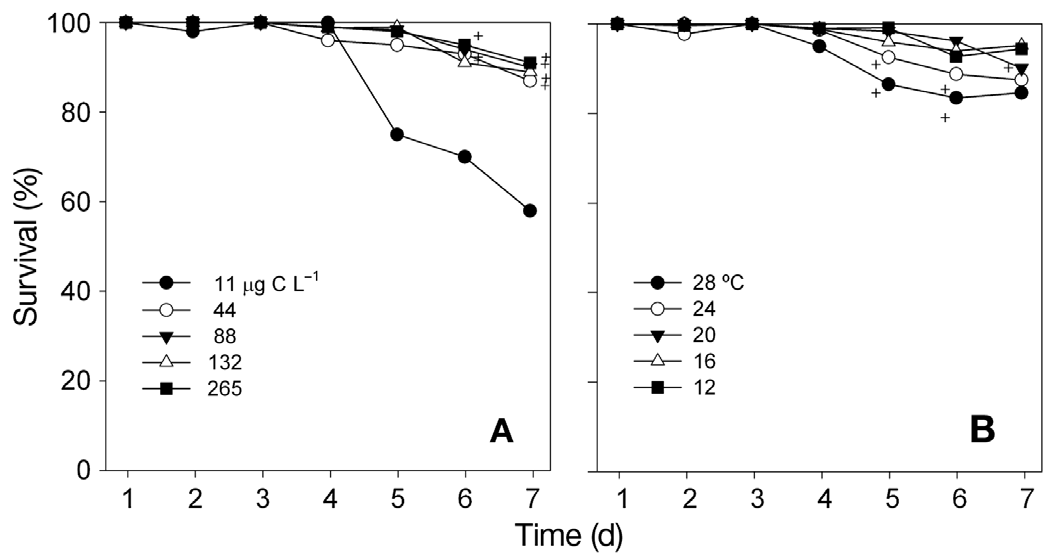

Fig. 2. Oithona davisae. Survival rates of early developmental stages reared for $7 \mathrm{~d}$ at (A) 5 food concentrations and (B) 5 temperatures. +: cohort was dominated by Naupliar Stage VI (NVI) and Copopodite Stage I (CI) (NVI-CI metamorphosis)

Table 2. Oithona davisae. Effect of food concentration on the median development time (MDT, d) and stage duration (SD, d) of early larval stages at $20^{\circ} \mathrm{C}$. NII to NVI: Naupliar Stages II to VI; CI: Copepodite Stage I

\begin{tabular}{|c|c|c|c|c|c|c|c|c|c|c|}
\hline & \multicolumn{10}{|c|}{ Food concentration $\left(\mu \mathrm{g} \mathrm{Cl}^{-1}\right)$} \\
\hline & \multicolumn{2}{|c|}{11} & \multicolumn{2}{|c|}{44} & \multicolumn{2}{|c|}{88} & \multicolumn{2}{|c|}{132} & \multicolumn{2}{|c|}{265} \\
\hline & MDT & $\mathrm{SD}$ & MDT & $\mathrm{SD}$ & MDT & $\mathrm{SD}$ & MDT & $\mathrm{SD}$ & MDT & $\mathrm{SD}$ \\
\hline NII & 2.54 & 1.22 & 1.14 & 0.98 & 1.16 & 0.94 & 1.16 & 0.80 & 1.17 & 0.84 \\
\hline NIII & 3.76 & 1.54 & 2.12 & 0.81 & 2.09 & 0.88 & 1.96 & 0.97 & 2.01 & 0.89 \\
\hline NIV & 5.30 & & 2.93 & 0.94 & 2.97 & 0.79 & 2.94 & 0.75 & 2.90 & 0.85 \\
\hline NV & & & 3.87 & 1.33 & 3.76 & 1.12 & 3.68 & 1.08 & 3.75 & 0.98 \\
\hline NVI & & & 5.20 & 1.83 & 4.89 & 1.72 & 4.76 & 1.62 & 4.74 & 1.56 \\
\hline $\mathrm{CI}$ & & & 7.03 & & 6.60 & & 6.39 & & 6.30 & \\
\hline
\end{tabular}

Ivlev's equation (Fig. 4A):

$$
D=D_{\max }\left(1-\mathrm{e}^{(-\beta C)}\right)
$$

where $D_{\max }$ is the maximum development rate $\left(\mathrm{d}^{-1}\right)$ and $\beta$ is a constant (rate at which development approaches the maximum development rate). The parameters for the fitted Ivlev's function across different stages are presented in Table 3. Food concentrations required to achieve $95 \%$ of the maximum development rate $\left(C_{\mathrm{D}}\right.$, satiating food concentration) ranged from 40 to $56 \mu \mathrm{g} \mathrm{Cl}^{-1}$, depending on the naupliar stage (Table 3 ).

Effects of temperature.Temperature had a clear effect on development times; MDT and all stage durations decreased with rising temperatures (Fig. 3, Table 4). Cohorts only reached CI within the $7 \mathrm{~d}$ incubation time at high temperatures $\left(20\right.$ to $\left.28^{\circ} \mathrm{C}\right)$. Similar to the food concentration experiments, naupliar development of Oithona davisae was equiproportional, but not isochronal. The functional relationships between temperature $\left(T,{ }^{\circ} \mathrm{C}\right)$ and MDT $\left(\mathrm{d}^{-1}\right)$ were well described $(\mathrm{p}<0.05)$ by Belehrádek's function (Fig. 4B):

$$
\mathrm{MDT}=a(T-\alpha)^{-2.05}
$$

where $a$ and $\alpha$ are constants (Corkett et al. 1986). The fitted Belehrádek's function for each naupliar stage and the applied temperature range are shown in Table 5. The equation parameter $a$ increased gradually with the age of developmental stages (Table 5). Across all temperatures tested, $Q_{10}$ values for development ranged from approximately 2.4 for NII and NIII stages (12 to $28^{\circ} \mathrm{C}$ ) to 1.6 for $\mathrm{CI}$ stages $\left(20\right.$ to $28^{\circ} \mathrm{C}$ ). At temperatures $<20^{\circ} \mathrm{C}$, no individuals reached the CI developmental stage. Within stages, $Q_{10}$ values were temperature dependent; for example, the NII produced $Q_{10}$ values of 4.41 at from 12 to $20^{\circ} \mathrm{C}$, but 1.19 at from 20 to $28^{\circ} \mathrm{C}$. Using a common range of temperature (20 to $28^{\circ} \mathrm{C}$ ) for all stages, $Q_{10}$ values increased from 1.2 for Stages NII and NIII to 1.6 for Stages NIV to CI.

\section{Body length and growth rates}

Effects of food concentration. Naupliar body length decreased at the lowest food concentration (ANOVA, p < 0.01; Tukey's test, $\mathrm{p}<0.01)$, with reductions ranging from $3 \%$ in Stage NII to $15 \%$ in Stage NV (Fig. 5A). Growth rates were exponential and consistent across food levels, except at the lowest food concentration (Fig. 6A; ANCOVA, $F=107.34, \mathrm{p}<$ 0.01). Naupliar specific growth rates $\left(G, \mathrm{~d}^{-1}\right)$ relative to food concentrations $\left(C, \mu \mathrm{g} \mathrm{C}^{-1}\right)$ followed a saturation curve (Ivlev's equation) expressed by the function (Fig. 7A):

$$
G=0.296\left(1-\mathrm{e}^{(-0.034 C)}\right), \mathrm{r}^{2}=0.97
$$

where 0.296 is the maximum growth rate $\left(d^{-1}\right)$ and 0.034 is a constant that indicates the rate at which growth approaches the maximum rate. The satiating food concentration $\left(C_{\mathrm{G}}\right)$ at which maximum naupliar growth became limited was $87 \mu \mathrm{C} \mathrm{Cl}^{-1}$.

Effects of temperature. Temperature had a significant effect and was inversely correlated to body length (Fig. 5B; ANOVA, p < 0.05). In early stages (NII to NIV), body size differences were only significant between the lowest and highest temperatures. For example, the body length for NIII individuals ranged from $114 \mu \mathrm{m}$ at $12^{\circ} \mathrm{C}$ to $107 \mu \mathrm{m}$ at $28^{\circ} \mathrm{C}$ (Tukey's test, $\mathrm{p}<0.05)$, with differences becoming more evident at later stages (NV to NVI) (Fig. 5B). 


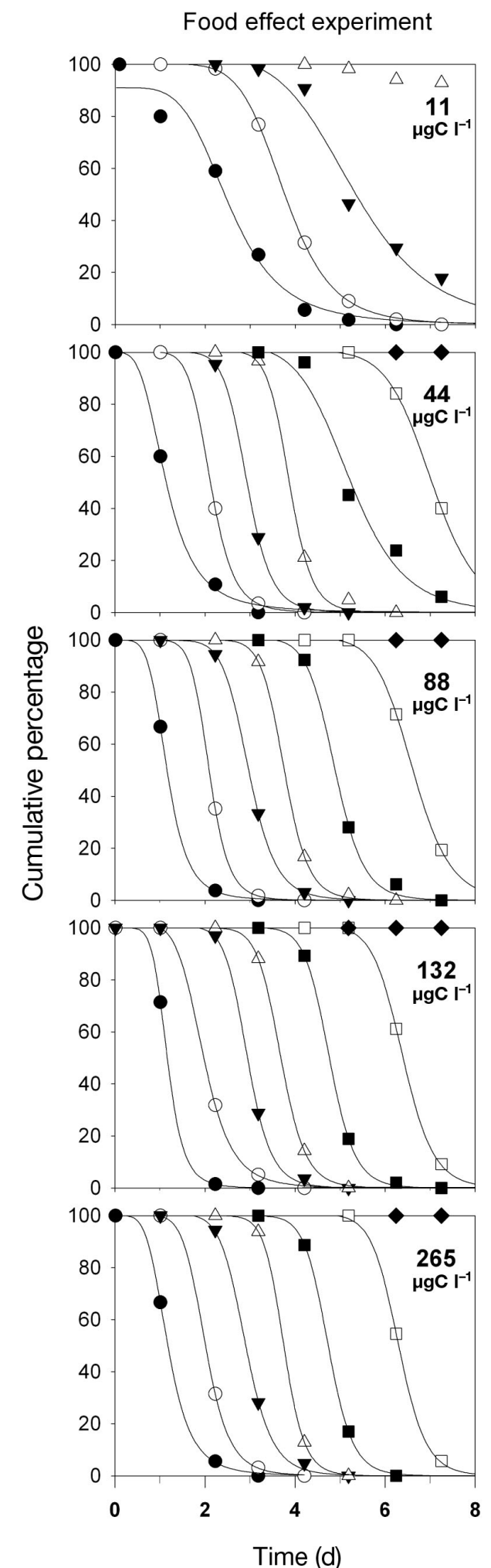

Temperature effect experiment
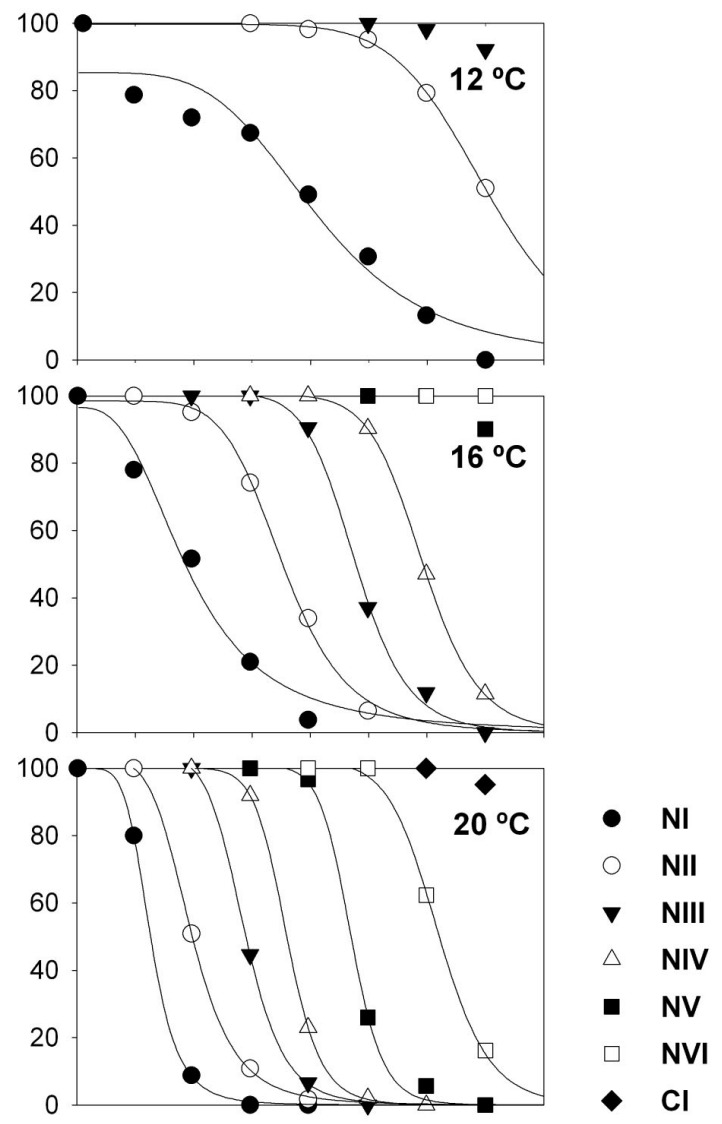

Time (d)

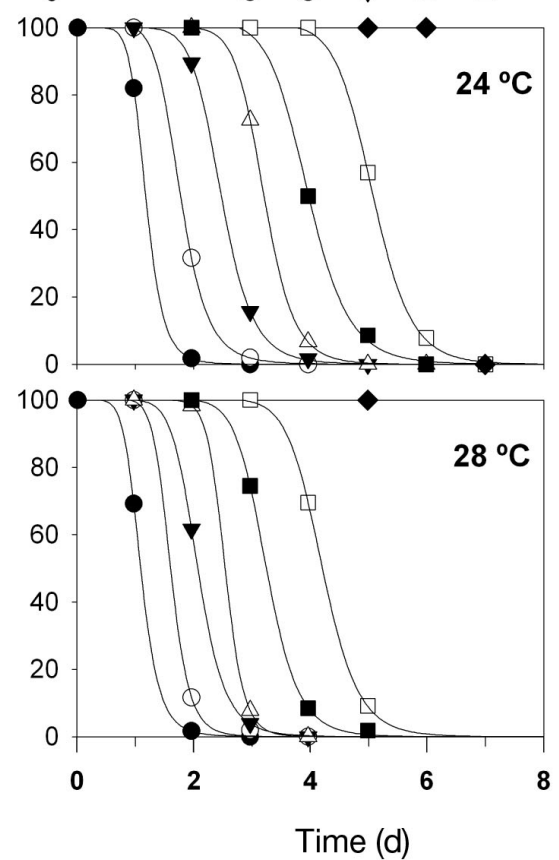

Fig. 3. Oithona davisae. Cumulative abundance percentages of all animals that have not yet passed a given stage, plotted against time. Left panels: for food concentration treatments; right panels: for temperature treatments. Successive stages from Naupliar Stage I (NI) to Copepodite Stage I (CI) are indicated by different symbols. Hill functions (Eq. 2) were fitted to the data, including all 100 and $0 \%$ values, which for clarity are not shown in the graphs except one, immediately before and after the occurrence of a stage, respectively. Stages older than CI are not shown 

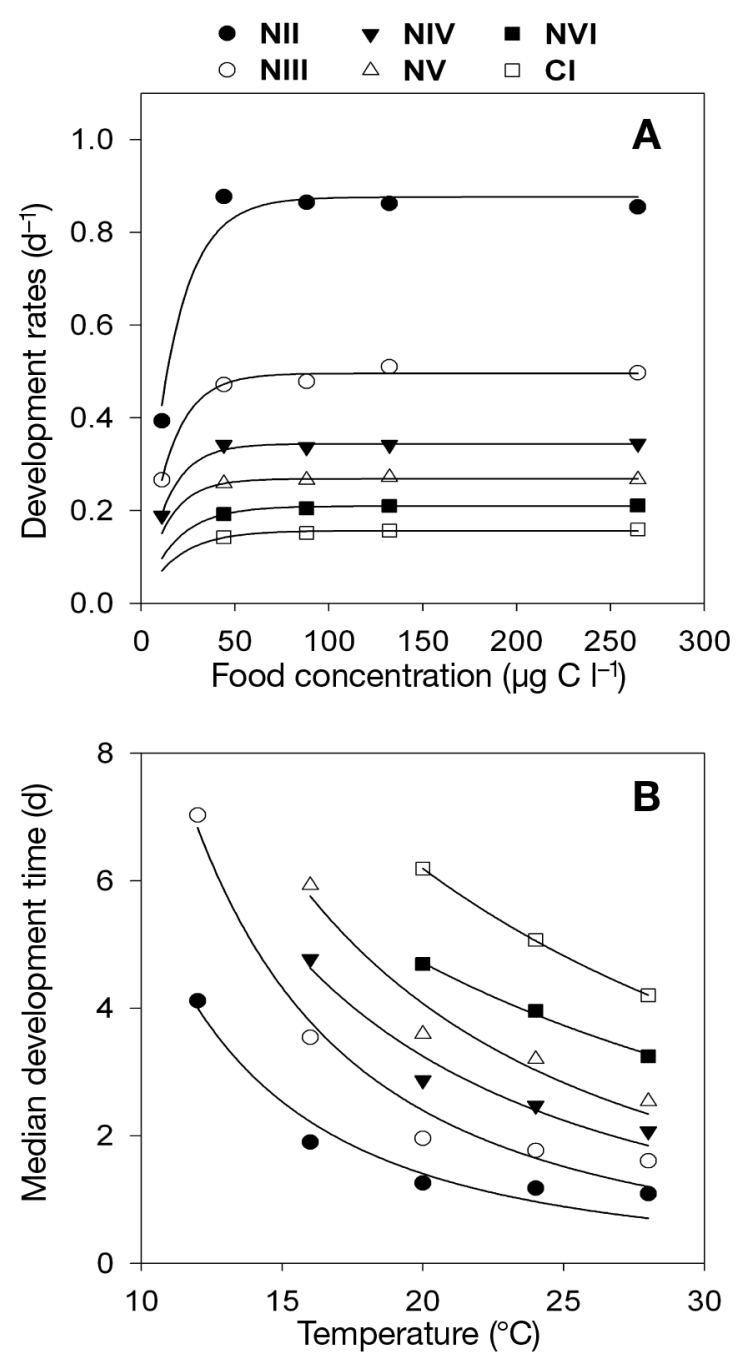

Fig. 4. Oithona davisae. (A) Relationships between food concentration and development rates for early larval stages. The fitted curves are described by Ivlev's functions. (B) Relationships between temperature and median development time for early larval stages under satiating food conditions. The fitted curves are described by Belehrádek functions
Table 3. Oithona davisae. Parameters of the Ivlev's equation (Eq. 9) used to describe the relationship between food concentration $\left(\mu \mathrm{g} \mathrm{C} \mathrm{l}^{-1}\right)$ and developmental rates $\left(D_{\max }\right.$ and $\left.\beta, \mathrm{d}^{-1}\right)$

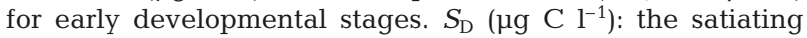
food concentration for maximum development; $r^{2}$ : coefficient of determination; SE: standard error. NII to NVI: Naupliar Stages II to VI $i$ CI: Copepodite Stage I

\begin{tabular}{|lcccc|}
\hline & $D_{\max }( \pm \mathrm{SE})$ & $\beta( \pm \mathrm{SE})$ & $\mathrm{r}^{2}$ & $S_{\mathrm{D}}$ \\
\hline NII & $0.87( \pm 0.02)$ & $0.061( \pm 0.008)$ & 0.96 & 49 \\
NIII & $0.49( \pm 0.05)$ & $0.070( \pm 0.005)$ & 0.98 & 43 \\
NIV & $0.34( \pm 0.04)$ & $0.073( \pm 0.005)$ & 0.99 & 41 \\
NV & $0.27( \pm 0.02)$ & $0.074( \pm 0.008)$ & 0.80 & 40 \\
NVI & $0.21( \pm 0.02)$ & $0.056( \pm 0.004)$ & 0.93 & 53 \\
CI & $0.16( \pm 0.02)$ & $0.053( \pm 0.005)$ & 0.88 & 56 \\
\hline
\end{tabular}

\section{DISCUSSION}

\section{Elemental composition $(\mathrm{C}, \mathrm{N})$}

For ecophysiology studies, such as ours and especially for those examining growth, it is important to express data in biomass-specific units to facilitate comparison across studies. It is also crucial to have concurrent, accurate and reliable estimates of biomass, or at least robust body length-weight relationships, since using literature relationships may produce severe bias. Intra-specific differences, origin and condition of organisms, previous food intake and the method of sample preservation can result in different body lengthweight relationships, especially when only longitudinal measurements are considered. For instance, the relationships we measured between body length and $\mathrm{C}$ weight for Oithona davisae copepodites differed from observations of the same species by Uye \& Sano (1998).

The C:N ratios observed in Oithona davisae nauplii are consistent with those ratios commonly reported for
Growth rates were exponential and dependent on temperature (Fig. 6A; ANCOVA, $F=13.81$, p < 0.01). Relationships between naupliar specific growth rates $\left(G, \mathrm{~d}^{-1}\right)$ and temperatures $\left(T,{ }^{\circ} \mathrm{C}\right)$ were established by the model (Fig. 7B):

$\log G=(0.053 \times T)-1.721, \mathrm{r}^{2}=0.87(12)$

$Q_{10}$ values for growth declined with rising temperatures (e.g. at 12 to $24^{\circ} \mathrm{C}$ $Q_{10}=4.8$; at 16 to $24^{\circ} \mathrm{C} Q_{10}=2.8$; at 20 to $\left.28^{\circ} \mathrm{C} Q_{10}=1.6\right)$. The $Q_{10}$ value was 3.6 across the range of temperatures tested in the experiments $\left(12\right.$ to $\left.28^{\circ} \mathrm{C}\right)$.
Table 4. Oithona davisae. Effect of temperature on median development time (MDT, days) and stage duration (SD, d) of early larval stages under satiating food conditions. NII to NVI: Naupliar Stages II to VI; CI: Copepodite Stage I

\begin{tabular}{|c|c|c|c|c|c|c|c|c|c|c|}
\hline & \multicolumn{2}{|c|}{12} & \multicolumn{2}{|c|}{16} & \multicolumn{2}{|c|}{20} & \multicolumn{2}{|c|}{24} & \multicolumn{2}{|c|}{28} \\
\hline & MDT & $\mathrm{SD}$ & MDT & $\mathrm{SD}$ & MDT & $\mathrm{SD}$ & MDT & $\mathrm{SD}$ & MDT & $\mathrm{SD}$ \\
\hline NII & 4.12 & 2.91 & 1.90 & 1.64 & 1.26 & 0.70 & 1.18 & 0.59 & 1.09 & 0.51 \\
\hline NIII & 7.03 & & 3.54 & 1.23 & 1.96 & 0.91 & 1.77 & 0.70 & 1.60 & 0.47 \\
\hline NIV & & & 4.77 & 1.16 & 2.87 & 0.73 & 2.47 & 0.73 & 2.07 & 0.47 \\
\hline NV & & & 5.93 & & 3.60 & 1.10 & 3.20 & 0.76 & 2.54 & 0.71 \\
\hline NVI & & & & & 4.69 & 1.50 & 3.96 & 1.11 & 3.25 & 0.96 \\
\hline CI & & & & & 6.19 & & 5.07 & & 4.20 & \\
\hline
\end{tabular}


Table 5. Oithona davisae. Parameters of the Belehrádek function (Eq. 10) used to describe the relationship between median development time (MDT, d) and temperature $\left(T,{ }^{\circ} \mathrm{C}\right)$ for early development stages. $r^{2}$ : coefficient of determination; SE: standard error; NII to NVI: Naupliar Stages II to VI; CI: Copepodite Stage I

\begin{tabular}{|ccccc|}
\hline & $a( \pm$ SE) & $\alpha( \pm$ SE) & $r^{2}$ & $\begin{array}{c}\text { Temp. range } \\
\left({ }^{\circ} \mathrm{C}\right)\end{array}$ \\
\hline NII & $650( \pm 231)$ & $0.04( \pm 2.30)$ & 0.94 & $12-28$ \\
NIII & $1114( \pm 230)$ & $0.8( \pm 1.4)$ & 0.97 & $12-28$ \\
NIV & $2423( \pm 893)$ & $-5.2( \pm 4.2)$ & 0.94 & $16-28$ \\
NV & $3181( \pm 1156)$ & $-5.8( \pm 4.3)$ & 0.95 & $16-28$ \\
NVI & $9721( \pm 1446)$ & $-21.4( \pm 3.2)$ & 0.99 & $20-28$ \\
CI & $11049( \pm 226)$ & $-18.6( \pm 0.4)$ & 0.99 & $20-28$ \\
\hline
\end{tabular}

marine copepods ( 3 to 14 ; Omori 1969, Postel et al. $2000)$. Since C:N ratios are related to lipid and protein ratios, the decrease in the $\mathrm{C}: \mathrm{N}$ ratio observed with $O$. davisae development may be indicative of the gradual decrease in yolk lipids as development proceeds.

\section{Survival}

Mortality in early developmental stages strongly affects population dynamics among marine copepods (Peterson \& Kimmerer 1994, Plourde et al. 2009). Stagespecific mortality depends on both intrinsic and external factors. Intrinsic factors that may affect early stage survival of copepods include shifts from yolk-related, endogenous foods to exogenous food sources. This food shift may explain the high, early mortality observed

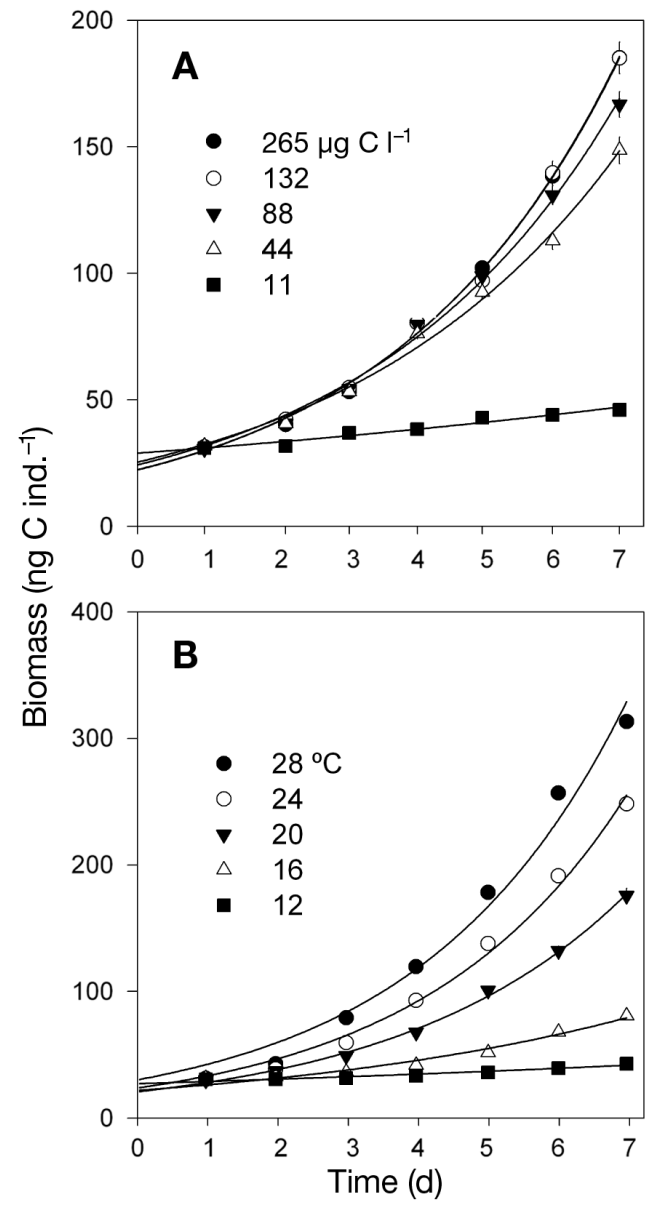

Fig. 6. Oithona davisae. Time course of carbon biomass of early larval stages in relation to (A) food concentration ( $\left.\mu \mathrm{g} \mathrm{Cl}^{-1}\right)$ and (B) temperature. Error bars represent $\pm \mathrm{SE}$
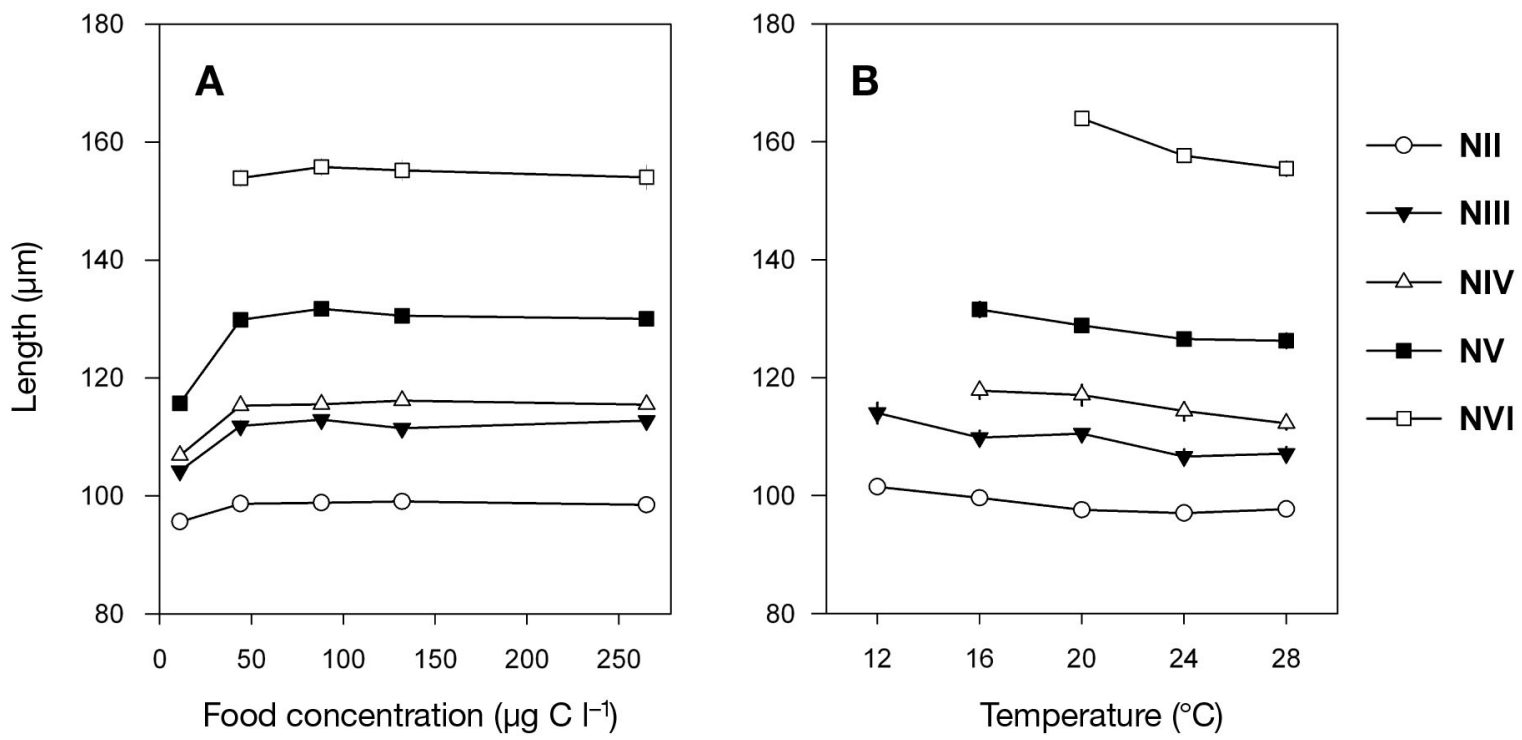

Fig. 5. Oithona davisae. (A) Effect of food concentration on length of naupliar stages at $20^{\circ} \mathrm{C}$. (B) Effect of temperature on length of naupliar stages under satiating food conditions 

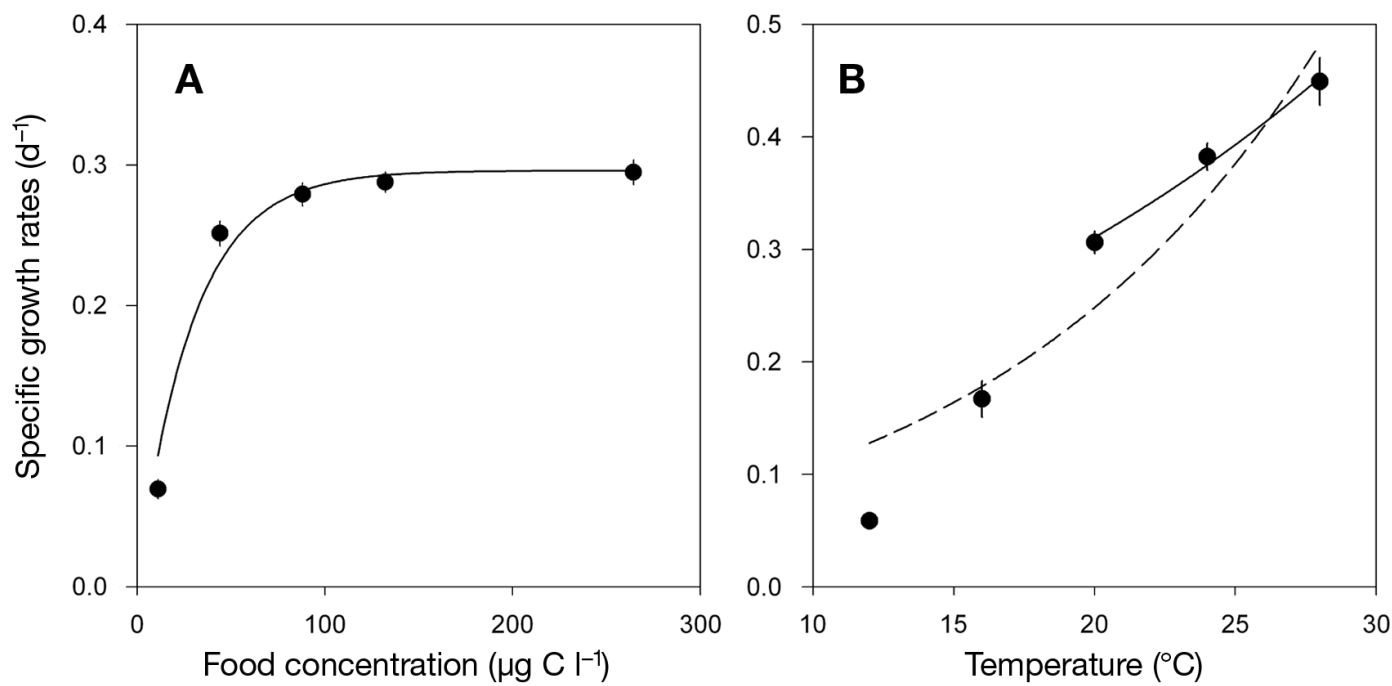

Fig. 7. Oithona davisae. (A) Specific growth rates $( \pm \mathrm{SE})$ of naupliar stages as a function of food concentration $\left(\mu \mathrm{g} C \mathrm{l}^{-1}\right)$. Fitted curves correspond to Ivlev's equation (see 'Results'). (B) Specific growth rates ( \pm SE) of naupliar stages as a function of temperature. Fitted curves correspond to exponential models. The equations are: $\log G=(0.053 \times T)-1.721, \mathrm{r}^{2}=0.99$, for temperatures between 20 and $28^{\circ} \mathrm{C}$ (continuous line) and $\log G=(0.053 \times T)-1.721, \mathrm{r}^{2}=0.87$ (dashed line), for the total range of temperature $\left(12\right.$ to $\left.20^{\circ} \mathrm{C}\right)$, where $G$ is the specific growth rate $\left(\mathrm{d}^{-1}\right), T$ is the temperature $\left({ }^{\circ} \mathrm{C}\right)$ and $\mathrm{r}^{2}$ is the correlation coefficient

among some species (Trujillo-Ortiz \& Arroyo-Ortega 1991). However, we did not observe this type of early mortality in Oithona davisae, which is consistent with observations that Oithona spp. nauplii start to feed after hatching (Uchima \& Hirano 1986). Another intrinsic factor affecting early mortality relates to the large morphological and physiological changes associated with copepod development, particularly with the metamorphosis from nauplii to copepodite (Epp \& Lewis 1980, Ferrari \& Dahms 2007). This could be the cause of increased mortality observed in our experiments during O. davisae transitions from NVI to CI, as occurs in other copepods (Lonsdale 1981).

Regarding external factors, in addition to predation and disease (virus, bacteria, parasites, etc.), copepod mortality is mainly affected by starvation and temperature. The following conditions can influence these factors: famine duration, lipid reserves, food quality and developmental stage (Paffenhöfer 1971, Calbet \& Alcaraz 1997, Ismar et al. 2008). Food concentrations that induce relevant mortality in Oithona davisae nauplii ( 11 $\left.\mu \mathrm{g} \mathrm{C}^{-1}\right)$ were lower than those commonly reported for calanoid nauplii studied in laboratory settings ( 36 to $100 \mu \mathrm{g} \mathrm{C} \mathrm{l}^{-1}$; Paffenhöfer 1971, Berggreen et al. 1988, Cook et al. 2007, Ismar et al. 2008). Moreover, mortality of $O$. davisae nauplii was only significant after $5 \mathrm{~d}$, suggesting that this species can withstand relatively long periods of poor food conditions.

As previously stated, food quality may influence naupliar mortality during development (Paffenhöfer 1971). The prey used in the present study (Oxyrrhis marina) are considered a high-quality food for Oithona davisae nauplii due to its morphology (i.e. optimal size; Saiz et al. unpubl. data), biochemical composition (essential lipids; Klein Breteler et al. 1999), motility (Uchima \& Hirano 1986) and digestibility (without a theca). Previously reported incidences of $100 \%$ mortality of $O$. davisae nauplii at high food concentrations (Uchima \& Hirano 1986) are in complete disagreement with our results. The high mortality observed by Uchima \& Hirano (1986) was probably a consequence of the poor nutritive quality of the prey used in their experiments ( $D u$ naliella spp.; Klein Breteler et al. 1999, Dahl et al. 2009).

We did not observe any temperature-related effects, except for faster development at higher temperatures. This observation suggests an accelerated transition from NVI to CI stages, along with its associated mortality.

\section{Development and growth rates}

Post-embryonic development in copepods can follow different patterns. Isochronal development (i.e. constant stage duration across the entire lifespan) has been frequently reported in calanoid copepods (Miller et al. 1977, Klein Breteler et al. 1982) and in the cyclopoid Oithona similis (Sabatini \& Kiørboe 1994). However, isochronal development was not observed in $O$. davisae nauplii. We noted 2 differences in the duration of naupliar stages relative to other copepods. First, in most calanoid copepods, pre-feeding stages are relatively short, but first-feeding stages (NII or NIII) are longer (Landry 1975, 1983). In contrast, early stages (NII) and late stages (NIV and NV) of O. davisae nau- 
plii were of similar duration, which is probably because feeding starts just after hatching. Second, $O$. davisae undergo long NVI stages, unlike other copepods in which NVI passes rapidly (Uchima 1979, Peterson 2001). Our results support the rule of equiproportional development (Corkett 1984), as opposed to the isochronal rule, which seems to be a pattern generally found in copepod development (Miller et al. 1977, Hart 1990, Peterson 2001).

As typically occurs in copepods (McLaren 1978), the development time of Oithona davisae nauplii decreased with rising temperatures. The naupliar development time estimated by Uye \& Sano (1998) based on theoretical assumptions (equiproportional rule) were $2 \mathrm{~d}$ longer than those stemming from our experimental results. At similar temperatures and under satiating food conditions, $O$. davisae development time (NI to $\mathrm{CI}$ ) is comparable to that of other marine cyclopoid and calanoid copepods, even at larger sizes (Hart 1990, Paffenhöfer 1993, Sabatini \& Kiørboe 1994, Peterson 2001). This is consistent with previous studies (Hart 1990, Sabatini \& Kiørboe 1994, Peterson 2001), which concluded that copepod development times in the presence of unlimited food resources were independent of adult body size. Therefore, despite the differences in size between cyclopoid and calanoid copepods, generation times and the potential for recruitment might be similar (Peterson 2001). However, $O$. davisae development levels off at food concentrations $\left(\sim 50 \mu \mathrm{g} \mathrm{C} \mathrm{l}^{-1}\right.$ at $\left.20^{\circ} \mathrm{C}\right)$ lower than those commonly reported for coastal calanoid nauplii (>200 $\mathrm{\mu g} \mathrm{C} \mathrm{l}^{-1}$ at $15^{\circ} \mathrm{C}_{\text {; }}$ Klein Breteler et al. 1982). While further confirmation is needed, this observation suggests a competitive advantage of $O$. davisae over other coastal copepods under low food conditions. Conversely, $O$. davisae showed higher satiating food concentrations for growth than for development, which was consistent with findings for other copepod species (Ban 1994, Campbell et al. 2001). Hence, nauplii could maintain maximum developmental rates at food concentrations that were limiting for somatic growth (i.e. development may be less sensitive than growth to food concentrations). This suggests that development and, consequently, recruitment may be prioritised over somatic growth for some copepod species.

It is difficult to compare our estimated naupliar growth rates with those from the literature, because available data are scarce and mostly examine calanoids (Calbet \& Alcaraz 1997, Campbell et al. 2001, Lee et al. 2003, Leandro et al. 2006). In the case of oithonids, our understanding is that naupliar growth rates under saturating food conditions have only been reported for Oithona similis examined under laboratory conditions (Sabatini \& Kiørboe 1994). These results were similar to our observations, albeit slightly higher $\left(0.20 \mathrm{~d}^{-1}\right.$ at $15^{\circ} \mathrm{C}_{i}$ Sabatini \& Kiørboe 1994$)$. The smaller size of Oithona spp. would lead one to deduce higher weight-specific metabolic rates (Lynch 1977, Ikeda et al. 2001). However, the growth rates of Oithona spp. nauplii appear to be lower than those frequently reported for calanoids $\left(0.27\right.$ to $0.50 \mathrm{~d}^{-1}$; Kiørboe \& Sabatini 1995, Calbet \& Alcaraz 1997, Leandro et al. 2006) and those predicted from global models (Huntley \& Lopez 1992, Hirst \& Lampitt 1998, Hirst \& Bunker 2003).

The influence of temperature $\left(Q_{10}\right)$ on growth rates was similar to the pattern mentioned above for naupliar development (NI to CI). Consistent with the Arrhenius equation, the $Q_{10}$ is temperature dependent and decreases with rising temperatures. Therefore, the typical application of uniform values of $Q_{10}$ calculated across different temperature ranges can result in errors in determining temperature effects on physiological rates. It is surprising that the relationship of growth rates to temperature did not follow the exponential model (i.e. Van't Hoff-Arrhenius law). As Oithona davisae is a thermophilic species experiencing its highest population densities during warm seasons (Uye \& Sano 1995, Nakane et al. 2008), we think that the lower temperatures used in our experiments $\left(12\right.$ and $\left.16^{\circ} \mathrm{C}\right)$ might be sub-optimal, resulting in deviation from the exponential model. The exponential model seems to fit best when high experimental temperatures are considered (Fig. 7).

\section{Ecological implications}

Laboratory experiments under controlled conditions are a fundamental tool for understanding the effects of environmental variables on the distribution and activity of marine zooplankton. Nonetheless, caution is required when extrapolating laboratory results to the field (e.g. bottle effects, crowding and lack of turbulence).

In addition to factors such as predation and salinity, development and growth rates of wild copepods can be affected by both temperature and food availability. Development and growth of marine copepods are frequently food-limited in natural settings (Hirst \& Bunker 2003, Saiz \& Calbet 2007). The degree of food limitation can be highly variable among groups/species and across life-history stages (Hirst \& Bunker 2003, Finlay \& Roff 2006). Food concentrations producing satiation in Oithona davisae nauplii were lower than in calanoid nauplii studied in laboratories (Klein Breteler et al. 1982, Berggreen et al. 1988, Calbet \& Alcaraz 1997, Leandro et al. 2006). Therefore, we expect that $O$. davisae would achieve maximum growth and development rates in nature with less food than calanoid 
nauplii. The satiating food concentration for the growth and development of $O$. davisae nauplii is relatively low given the high food concentrations ( 2 to $50 \mu \mathrm{g}$ chlorophyll $\mathrm{a}^{-1}$ ) of eutrophic coastal habitats (Uye \& Sano 1995, Gifford et al. 2007, Nakane et al. 2008). This food concentration is equivalent to 94 to $1410 \mu \mathrm{g} \mathrm{Cl}^{-1}$, using an average conversion factor of 47 (Riemann et al. 1989). In addition to food quantity, food quality (e.g. size, palatability, motility, nutritional value) should be considered when expressing food limitation in nature. $O$. davisae nauplii and adults only feed on relatively large and motile prey (Uchima \& Hirano 1986, Tsuda \& Nemoto 1988, Uchima 1988, Broglio et al. 2004, Atienza et al. 2006, Henriksen et al. 2007), which substantially reduces the amount of food available for ingestion. During warm seasons, the biomass of potential prey in some eutrophic waters inhabited by $O$. davisae is frequently close to their critical food concentration for development $\left(\sim 50 \mu \mathrm{g} \mathrm{C} \mathrm{l}^{-1}\right.$; Gifford et al. 2007 and $>500$ cells $\mathrm{ml}^{-1}$; Nakane et al. 2008). In addition, field naupliar growth rates reported for other Oithona species (Hopcroft \& Roff 1998) are similar to those reported for $O$. davisae nauplii under satiating food conditions and at similar temperatures $\left(0.49 \mathrm{~d}^{-1}\right.$ at $28^{\circ} \mathrm{C}$ ). The low satiating threshold exhibited by Oithona spp. nauplii would provide a competitive advantage over other copepods in these environments and under oligotrophic conditions.

Many hypotheses have been offered as to why oithonids are so abundant and ubiquitous relative to calanoids (Lampitt 1978, Lampitt \& Gamble 1982, Paffenhöfer 1993, Castellani et al. 2005b). Copepod life strategies are adapted to food fluctuations. For example, when primary production declines, many calanoid species produce resting eggs that accumulate in sediments and hatch prior to the onset of the spring bloom. Oithonids do not produce resting eggs and must adapt to tolerate periods of low food availability and to maintain their populations throughout the year.

The success of oithonids over calanoids has been attributed to their wide array of prey preferences (Lampitt 1978, Uchima 1988, González \& Smetacek 1994, Calbet et al. 2000) and low metabolic rates (Lampitt \& Gamble 1982, Paffenhöfer 1993, Castellani et al. 2005). Differences in the motion/feeding behaviour may contribute to differences in metabolic requirements between calanoids and oithonids. Our study shows that development rates of Oithona spp. nauplii are similar to those of calanoid nauplii, but growth rates of Oithona spp. nauplii are lower than those of calanoid nauplii. In addition, naupliar development of Oithona spp. saturates at lower concentrations. Thus, Oithona spp. development is completed sooner and results in smaller sized individuals than that of calanoid copepods inhabiting oligotrophic regions. Moreover, in en- vironments, such as oceans, with substantial predation (Verity \& Smetacek 1996), reduced size and low motility may offer a competitive advantage that reduces predation risk. In summary, our study suggests that Oithona spp. in marine ecosystems may have an advantage over other copepods because of differences in food requirements that maximise survival and rates of development and growth.

Acknowledgements. We thank P. Jimenez, E. Velasco and J.Movilla for their help in maintaining the algae and copepod cultures. This work was funded by a PhD fellowship to R.A. (BES-2005-7491) from the Spanish Ministry of Education and Science and supported by MICROROL (CTM2004-02775), OITHONA (CTM2007-60052), Intramural (200630I226) and PERFIL (CTM2006-12344) research projects from the same ministry.

\section{LITERATURE CITED}

Alcaraz M (1977) Muestreo cuantitativo de zooplankton: análisis comparativo de la eficacia de mangas y botellas en un sistema estuárico. Investig Pesq 41:285-294

Atienza D, Calbet A, Saiz E, Alcaraz M, Trepat I (2006) Trophic impact, metabolism, and biogeochemical role of the marine cladoceran Penilia avirostris and the co-dominant copepod Oithona nana in NW Mediterranean coastal waters. Mar Biol 150:221-235

$>$ Ban S (1994) Effect of temperature and food concentration on post embryonic development, egg production and adult body size of calanoid copepod Eurytemora affinis. J Plankton Res 16:721-735

> Berggreen U, Hansen B, Kiørboe T (1988) Food size spectra, ingestion and growth of the copepod Acartia tonsa during development: implications for determination of copepod production. Mar Biol 99:341-352

Björnberg TKS (1986) The rejected nauplius: a commentary. Syllogeus 58:232-236

Broglio E, Saiz E, Calbet A, Trepat I, Alcaraz M (2004) Trophic impact and prey selection by crustacean zooplankton on the microbial communities of an oligotrophic coastal area (NW Mediterranean Sea). Aquat Microb Ecol 35:65-78

Calbet A, Alcaraz M (1997) Growth and survival rates of early developmental stages of Acartia grani (Copepoda: Calanoida) in relation to food concentration and fluctuations in food supply. Mar Ecol Prog Ser 147:181-186

Calbet A, Landry M, Scheinberg R (2000) Copepod grazing in a subtropical bay: species-specific responses to a midsummer increase in nanoplankton standing stock. Mar Ecol Prog Ser 193:75-84

Calbet A, Garrido S, Saiz E, Alcaraz A, Duarte CM (2001) Annual zooplankton succession in coastal NW Mediterranean waters: the importance of the smaller size fractions. J Plankton Res 23:319-331

Campbell RG, Wagner MM, Teegarden GJ, Boudreau CA, Durbin EG (2001) Growth and development rates of the copepod Calanus finmarchicus reared in the laboratory. Mar Ecol Prog Ser 221:161-183

Castellani C, Irigoien X, Harris RP, Lampitt RS (2005a) Feeding and egg production of Oithona similis in the North Atlantic. Mar Ecol Prog Ser 288:173-182

Castellani C, Robinson C, Smith T, Lampitt RS (2005b) Temperature affects respiration rate of Oithona similis. Mar Ecol Prog Ser 285:129-135 
Castellani C, Irigoien X, Harris RP, Holliday NP (2007) Regional and temporal variation of Oithona spp. biomass, stage structure and productivity in the Irminger Sea, North Atlantic. J Plankton Res 29:1051-1070

Cook KB, Bunker A, Hay S, Hirst AG, Speirs DC (2007) Naupliar development times and survival of the copepods Calanus helgolandicus and Calanus finmarchicus in relation to food and temperature. J Plankton Res 29:757-767

Corkett CJ (1984) Observations on development in copepods. Crustaceana 7(Suppl):150-153

Corkett CJ, McLaren IA, Sevigny JM (1986) The rearing of the marine calanoid copepods Calanus finmarchicus (Gunnerus), C. glacialis Jaschnov and C. hyperboreus Krøyer with comments on the equiproportional rule. Syllogeus 58:539-546

Dahl U, Rubio Lind C, Gorokhova E, Eklund B, Breitholtz M (2009) Food quality effects on copepod growth and development: implications for bioassays in ecotoxicological testing. Ecotoxicol Environ Saf 72:351-357

Epp RW, Lewis WM (1980) The nature and ecological significance of metabolic changes during the life history of copepods. Ecology 61:259-264

Ferrari FD, Dahms HU (2007) Post-embryonic development of the Copepoda. Crustac Monogr 8:1-226

Ferrari FD, Orsi J (1984) Oithona davisae, new species, and Limnoithona sinensis (Burckhardt, 1912) (Copepoda: Oithonidae) from the Sacramento-San Joaquin Estuary, California. J Crustac Biol 4:106-126

Finlay K, Roff JC (2006) Ontogenetic growth rate responses of temperate marine copepods to chlorophyll concentration and light. Mar Ecol Prog Ser 313:145-156

Fryer G (1986) Structure, function and behaviour, and the elucidation of evolution in copepods and other crustaceans. Syllogeus 58:150-157

Gallienne CP, Robins DB (2001) Is Oithona the most important copepod in the world's oceans? J Plankton Res 23: 1421-1432

Gifford SM, Rollwagen-Bollens G, Bollens SM (2007) Mesozooplankton omnivory in the upper San Francisco Estuary. Mar Ecol Prog Ser 348:33-46

> González HE, Smetacek V (1994) The possible role of the cyclopoid copepod Oithona in retarding vertical flux of zooplankton faecal material. Mar Ecol Prog Ser 113:233-246

Hart RC (1990) Copepod post-embryonic durations: pattern, conformity, and predictability. The realities of isochronal and equiproportional development, and trends in the copepodid-naupliar duration ratio. Hydrobiologia 206: 175-206

Henriksen CI, Saiz E, Calbet A, Hansen BW (2007) Feeding activity and swimming patterns of Acartia grani and Oithona davisae nauplii in the presence of motile and nonmotile prey. Mar Ecol Prog Ser 331:119-129

Hernández-Molejón OG, Álvarez-Lajonchère L (2003) Culture experiments with Oithona oculata Farran, 1913 (Copepoda: Cyclopoida), and its advantages as food for marine fish larvae. Aquaculture 219:471-483

Hirakawa K (1988) New records of the North Pacific coastal planktonic copepods, Acartia omorii (Acartiidae) and Oithona davisae (Oithonidae) from southern Chile. Bull Mar Sci 42:337-339

Hirst AG, Bunker AJ (2003) Growth of marine planktonic copepods: global rates and patterns in relation to chlorophyll $a$, temperature, and body weight. Limnol Oceanogr 48:1988-2010

Hirst AG, Kiørboe T (2002) Mortality of marine planktonic copepods: global rates and patterns. Mar Ecol Prog Ser 230:195-209
Hirst AG, Lampitt RS (1998) Towards a global model of in situ weight-specific growth in marine planktonic copepods. Mar Biol 132:247-257

> Hopcroft RR, Roff JC (1998) Zooplankton growth rates: the influence of size in nauplii of tropical marine copepods. Mar Biol 132:87-96

- Huntley M, Boyd C (1984) Food-limited growth of marine zooplankton. Am Nat 124:455-478

> Huntley ME, Lopez MDG (1992) Temperature-dependent production of marine copepods: a global synthesis. Am Nat 140:201-242

Ikeda T, Kanno Y, Ozaki K, Shinada A (2001) Metabolic rates of epipelagic marine copepods as a function of body mass and temperature. Mar Biol 139:587-596

> Ismar SMH, Hansen T, Sommer U (2008) Effect of food concentration and type of diet on Acartia survival and naupliar development. Mar Biol 154:335-343

> Kiørboe T, Sabatini M (1995) Scaling of fecundity, growth and development in marine planktonic copepods. Mar Ecol Prog Ser 120:285-298

Klein Breteler WCM, Fransz HG, González SR (1982) Growth and development of four calanoid copepod species under experimental and natural conditions. Neth J Sea Res 16: 195-207

Klein Breteler WCM, Schogt N, Baas M, Schouten S, Kraay GW (1999) Trophic upgrading of food quality by protozoon's enhancing copepod growth: role of essential lipids. Mar Biol 135:191-198

- Lampitt RS (1978) Carnivorous feeding by a small marine copepod. Limnol Oceanogr 23:1228-1231

> Lampitt RS, Gamble JC (1982) Diet and respiration of the small planktonic marine copepod Oithona nana. Mar Biol 66:185-190

> Landry MR (1975) The relationship between temperature and the development of life stages of the marine copepod Acartia clausi Giesbr. Limnol Oceanogr 20:854-857

- Landry MR (1983) The development of marine calanoid copepods with comment on the isochronal rule. Limnol Oceanogr 28:614-624

Last JM (1980) The food of twenty species of fish larvae in the west-central North Sea. Fish Res Tech Rep Dir Fish Res (GB) 60:1-44

> Leandro SM, Tiselius P, Queiroga H (2006) Growth and development of nauplii and copepodites of the estuarine copepod Acartia tonsa from southern Europe (Ria de Aveiro, Portugal) under saturating food conditions. Mar Biol 150: 121-129

> Lee HW, Ban S, Ikeda T, Matsuishi T (2003) Effect of temperature on development, growth and reproduction in the marine copepod Pseudocalanus newmani at satiating food condition. J Plankton Res 25:261-271

> Lonsdale DJ (1981) Influence of age-specific mortality on the life history traits of two estuarine copepods. Mar Ecol Prog Ser 5:333-340

> Lynch M (1977) Fitness and optimal body size in zooplankton populations. Ecology 58:763-774

McLaren IA (1978) Generation lengths of some temperate marine copepods: estimation, prediction and implications. J Fish Res Board Can 35:1330-1342

Miller CB, Johnson JK, Heinle DR (1977) Growth rules in the marine copepod genus Acartia. Limnol Oceanogr 22: 326-335

Nakane T, Nakata K, Bouman H, Platt T (2008) Environmental control of short-term variation in the plankton community of inner Tokyo Bay, Japan. Estuar Coast Shelf Sci 78:796-810

> Omori M (1969) Weight and chemical composition of some important oceanic zooplankton in the North Pacific Ocean. 
Mar Biol 3:4-10

Paffenhöfer GA (1971) Grazing and ingestion of nauplii, copepodids and adults of the marine planktonic copepod Calanus helgolandicus. Mar Biol 11:286-298

Paffenhöfer GA (1993) On the ecology of marine cyclopoid copepods (Crustacea, Copepoda). J Plankton Res 15:37-55

$>$ Pelegri S, Dolan J, Rassoulzadegan F (1999) Use of high temperature catalytic oxidation (HTCO) to measure carbon content of microorganisms. Aquat Microb Ecol 16:273-280

Peterson WT (2001) Patterns in stage duration and development among marine and freshwater calanoid and cyclopoid copepods: a review of rules, physiological constraints, and evolutionary significance. Hydrobiologia 453/454:91-105

Peterson WT, Kimmerer WJ (1994) Processes controlling recruitment of the marine calanoid copepod Temora longicornis in Long Island Sound: egg production, egg mortality, and cohort survival rates. Limnol Oceanogr 39:1594-1605

Plourde S, Maps F, Joly P (2009) Mortality and survival in early stages control recruitment in Calanus finmarchicus. J Plankton Res 31:371-388

Postel L, Fock H, Hagen W (2000) Biomass and abundance. In: Harris RP et al. (eds) ICES zooplankton methodology manual. Academic Press, San Diego, p 83-192

Riemann B, Simonsen P, Stensgaard L (1989) The carbon and chlorophyll content of phytoplankton from various nutrient regimes. J Plankton Res 11:1037-1045

Sabatini M, Kiørboe T (1994) Egg production, growth and development of the cyclopoid copepod Oithona similis. J Plankton Res 16:1329-1351

Saiz E, Calbet A (2007) Scaling of feeding in marine calanoid copepods. Limnol Oceanogr 52:668-675

Saiz E, Calbet A, Broglio E (2003) Effects of small-scale turbu-

Editorial responsibility: Hans Heinrich Janssen, Oldendorf/Luhe, Germany lence on copepods: the case of Oithona davisae. Limnol Oceanogr 48:1304-1311

Trujillo-Ortiz A, Arroyo-Ortega JE (1991) Analysis of mortality and expectation of life of Acartia californiensis Trinast (Calanoid: Copepod) under laboratory conditions. Cienc Mar 17:11-18

$>$ Tsuda A, Nemoto T (1988) Feeding of copepods on natural suspended particles in Tokyo Bay, Japan. J Oceanogr Soc Jpn 44:217-227

Turner JT (2004) The importance of small planktonic copepods and their roles in pelagic marine food webs. Zool Stud 43:255-266

Uchima M (1979) Morphological observation of developmental stages in Oithona brevicornis (Copepoda, Cyclopoida). Bull Plankton Soc Japan 26:59-76

> Uchima M (1988) Gut content analysis of neritic copepods Acartia omorii and Oithona davisae by a new method. Mar Ecol Prog Ser 48:93-97

Uchima M, Hirano R (1986) Food of Oithona davisae (Copepoda: Cyclopoida) and the effect of food concentration at first feeding on the larval growth. Bull Plankton Soc Japan 33:21-28

> Uye S, Sano K (1995) Seasonal reproductive biology of the small cyclopoid copepod Oithona davisae in a temperate eutrophic inlet. Mar Ecol Prog Ser 118:121-128

Uye S, Sano K (1998) Seasonal variations in biomass, growth rate and production rate of the small cyclopoid copepod Oithona davisae in a temperate eutrophic inlet. Mar Ecol Prog Ser 163:37-44

Verity PG, Smetacek V (1996) Organism life cycles, predation, and the structure of marine pelagic ecosystems. Mar Ecol Prog Ser 130:277-293

Submitted: October 28, 2009; Accepted: April 15, 2010 Proofs received from author(s): June 22, 2010 